九州大学学術情報リポジトリ

Kyushu University Institutional Repository

FAUNAL AND BIOLOGICAL STUDIES ON THE INSECTS OF PADDY FIELDS IN ASIA. IV. AQUATIC AND SEMIAQUATIC HETEROPTERA FROM THE PHILIPPINES

Yano, Koji

Miyamoto, Syoiti

Gabriel, B. P.

https://doi.org/10.5109/2409

出版情報: ESAKIA. 16，pp.5-32，1981-03. Entomological Laboratory，Faculty of Agriculture， Kyushu University

バージョン：

権利関係 : 


\title{
FAUNAL AND BIOLOGICAL STUDIES ON THE INSECTS OF PADDY FIELDS IN ASIA. IV. AQUATIC AND SEMIAQUATIC HETEROPTERA FROM THE PHILIPPINES ${ }^{12)}$
}

\author{
Kôjı Yano, Syôiti Miyamoto and B. P. Gabriel \\ Laboratory of Applied Entomology, Faculty of Agriculture, Yamaguchi University, \\ Yamaguchi 753, Japan; Chikushi Jogakuen Junior College, Dazaifu-cho, \\ Chikushi-gun, Fukuoka 818-01, Japan; and Department of \\ Entomology, College of Agriculture, University of \\ the Philippines at Los Baños, College, \\ Laguna 3720, Philippines
}

\begin{abstract}
Aquatic and semiaquatic Heteroptera collected from the Philippine paddy water in $\mathbf{1 9 7 9}$ are enumerated. A total of 17 species (717 specimens) belonging to 11 families are listed with notes including 2 new species, Paraplea davaoensis Miyamoto (Pleidae) and Anisops yanoi Miyamoto (Notonectidae). Previous records of these bugs from the paddy water of the world are also reviewed.
\end{abstract}

Aquatic species of Heteroptera dwelling in paddy fields have hardly been accorded any attention in insect pest control which has been carried up to the present in the rice areas of the world. Fragmental records on their occurrence in paddy water, however, have been presented. Yet no extensive works have been done before anywhere else. Several papers such as Moretti (1932) in Italy, Fernando (1959) in Sri Lanka, Service (1973, 1977) in Kenya, Heckman (1974, 1979) in Laos and Thailand and Polhemus and Reisen (1976) in the Philippines reported around 15 species from the respective localities, and these are the prominent ones among the papers concerned. Among the species concerned, Microvelia species may be the only exception to have been observed by several authors as predators of plant- and leafhoppers in paddy fields. Aquatic fauna of paddy water covering fishes and other animals including insects, however, have been reported by Fernando (1956) and others. It is still true that the aquatic insect fauna of the environment has not been

1) Partial result of Grant-in-Aid for Overseas Scientific Survey, No. 40412 (Principal investigator: Prof. Y. Hirashima) from the Ministry of Education, Science and Culture.

2) Publication of this paper was financially supported by Grant-in-Aid for Overseas Scientific Survey, No. 504337 (Principal investigator : Prof. Y. Hirashima) from the Ministry of Education, Science and Culture.

Acknowledgement. is made to the Ministry of Education, Science and Culture, Japanese Government, for the grants mentioned above. 
focussed well on Heteroptera as stated above,

During the field surveys on the plant- and leafhoppers injurious to rice and their natural enemies made in the Philippines in 1979 (Hirashima, 1981), aquatic and semiaquatic Heteroptera found in paddy water were collected by the first author in co-operation with the third author, and identified by the second author who is also responsible for the descriptions of new species. It is known that these groups of Heteroptera are mostly predaceous and feed on various insects including plant- and leafhoppers. The work has been done consequently along the purpose of the project and as planned by the first author (Yano, 1978). Though the collection is not big and informations on the biology were scarcely obtained, the result is enumerated here for further studies with a bibliographical review on the occurrence of the groups from the paddy water of the world. Aquatic Coleoptera collected along with the present material will be treated elsewhere.

The first author wishes to express his sincere gratitude to Dr. Y. Hirashima of Kyushu University, project leader, for his kind arrangement in joining the project. He is thankful to Dr. K. Aizawa, Dr. K. Morimoto, Dr. C. R. Baltazar, Mr. P. W. Resma and Mr. L. E. Padua for their help in collecting material and other ways. The kind help of Dr. K. Yasumatsu and Dr. C. H. Fernando for the literature and other ways is also greatly appreciated. Further, he is also grateful to entomologists and other officials who kindly cooperated to our field works in the Philippines.

\section{Materials and localities visited}

Field surveys mentioned above have been done in Luzon and Mindanao of the Philippines in 1979. Many places were visited for the project, and collections on the aquatic insects of paddy water were made at the following four places on the dates enclosed in parentheses. Collections were made by an insect net $(42 \mathrm{~cm}$ in diameter and $30 \mathrm{~cm}$ in depth) which was reformed from ordinary sweep net by cutting its length.

Luzon. Banaue, Ifugao (July 27-31 and August 1)

Bay, Laguna (August 14)

Mindanao. Tugbok, Davao City (August 28-30)

Bislig, Surigao del Sur (September 1-4)

General situations of these places are partly referred to Yasumatsu et al. (1975). The following additional notes on these places are mentioned here especially for the aquatic insect collections concerned.

Banaue (Fig. 1). This is the place famous for its rice terraces situated on rather steep slopes of mountains at an elevation of about 1300 meters or more above sea level. Narrow paddy fields are terraced by stone walls, and native variety of rice have been cultivated without applying insecticides and fertilizers. Paddy fields around Banaue were in the midst of harvest when the surveys were done. Almost all paddies regardless of 
harvest hold water owing to the rainy season. Collections on aquatic insects were made at several paddies which were not harvested and had some vegetation of weeds.

Bay. The rice plants of paddy field where collections on aquatic insects were done were about $60 \mathrm{~cm}$ in height. Almost all paddy fields around there contain so much water. The paddy water investigated was partly running very slowly to the exit irrigation ditch owing to current heavy rains.

Tugbok (Fig. 2). Three paddy fields in a row were selected for collections. Irrigation water was flowing to these paddies for the next crop of rice, and no rice plant was planted then, and no weed was seen except for some floating debris. Nurseries were seen near the place. Rice plants of paddies around the place were in their tillering and flowering stages.

Bislig (Fig. 3). Paddy fields belonging to PICOP (Paper Industries Corporation of the Philippines) were visited for the project. Rice plants there were in the tillering stage to mature. The paddies where the collections of the aquatic insects were made were with rice plants of tillering stage and were almost drying up owing to poor rain-fall except for one tiny spot where paddy water still contained with many aquatic insects. Irrigation ditch by the paddy field mentioned above kept water, and collectings were made also at the ditch.

As mentioned above, these four places investigated are quite different from each other in terms of the condition of paddy water, growing stages of rice plants, and its surrounding environment. So, the notes in some respects in this paper such as distribution, abundance and others for the species collected is limited to a certain extent.

\section{Former record on the aquatic and semiaquatic Heteroptera from paddy water of the world}

So far as we are aware, the following records on the aquatic and semiaquatic Heteroptera collected from paddy water were seen. These are summarized in Table 1 . Some references quoted in the table (Reference B) mention the general knowledge on the paddy dwellings of respective species without giving any collecting data. Former records are reviewed chronologically in the following lines. Original scientific names are cited in parentheses when it is different from the present usage. Those not mentioned in the following lines are referred to the footnotes of Table 1.

1900-1949. Okada (1900) mentioned Sigarasubstriata attacking planthoppers in paddy fields in Shizuoka, Japan. He also observed a species attacking planthoppers and running on water surface of Japanese paddy fields. According to him this species belongs to $\operatorname{Re}-$ duviidae, but his notes reveal species belonging to Veliidae and Hebridae also. His description almost fits to the character of Hebridae except for the ovipositor. Ito (1918) recorded that Neparubra ( $N$. cinema) cut through the base of the young rice-plant in Argentina. Nawa (1924) mentioned that 4 aquatic Heteroptera, Ochterus marginatus flavomarginatus (Pelogonus flavomarginatus), Saldula recticollis (Salda recticollis), Paraplea indistinguenda (Plea indistinguenda) and Hydrometra albolineata ( $H$. vittata), are predaceous to planthoppers in Japanese paddy fields. He also indicated the occurrence of Lethocerus deyrollei and Lac- 
cotrephes japonensis in paddy water. Sakai (1932, 1933) reported Microvelia douglasi feeding on leafhoppers in Japan. Moretti (1932) mentioned about 12 species belonging to 8 families of aquatic Heteroptera occurring in paddy field of Italy, and gave brief descriptions on their larvae and/or adults. Lundblad (1933) recorded 13 species belonging to 8 families of aquatic Heteroptera collected from paddy fields of Sumatra (12 species) and Java (1 species). Sawa (1935) studied the soil fauna of levee by paddy field in the winter (December to April) near Mito City, Japan, and found 25 individuals of Veliidae (specific name was not given but probably Microvelia species) from the soil mainly within $3 \mathrm{~cm}$ from the surface. Hutchinson (1940) reported 3 species of Micronecta, quadristrigata, scutellaris scutellaris and thyesta, collected from Indian paddy fields. Esaki (1941) recorded three aquatic Heteroptera, Ranatra unicolor, Diplonychus japonicus and Ilyocoris cimicoides (Naucoris cimicoides) from the paddy field of N. China. Yago (1943) mentioned that Lethocerus deyrollei (Kirkaldyiadeyrollii) is injurious to rice seedlings and young fishes in Japan. Rice seedlings are uprooted by the bug, he stated.

1950-1969. Brooks (1951) described Anisopsnodulata from the Philippines which was collected from paddy fields of Pangasinan. Esaki and Miyamoto (1955) mentioned that Microvelia douglasi in Japan attacks Reciliadorsalis and probably Nephotettix cincticeps and Sogatella furcif era als 0 . Oho and Fuzii (1956) found the rather high population density of Microvelia douglasi in less sprayed paddy fields of Saga Prefecture, Japan, when they made investigations on the influence of chemical control. Oho and Miyahara (1957) also reported that Microvelia douglasi is a predator of Nephotettix cincticeps in Kyushu, Japan. Weerekoon and Samarasinghe (1958) studied soil fauna of a paddy field in Sri Lanka and found one species each of the following genera: Microvelia, Mesovelia, Ranatra, Diplonychus and Micronecta. Fernando (1959) listed 13 species belonging to 7 families of aquatic Heteroptera taken in paddy fields in Sri Lanka, but no collecting data were given. Fernando (1961) noted that Diplonychusrusticus (Sphaerodema rusticum) was common in paddy fields of Sri Lanka. Kobayashi (1961) listed 8 aquatic Heteroptera predaceous to plant- and leafhoppers in Japanese paddy fields based on the previous knowledge. These are Hebrus nipponicus, Hydrometra albolineata, Microvelia douglasi, M. horvathi, Saldula saltatoria, Saldula recticollis (Salda recticollice), $\mathbf{O}$ chterus marginatus flavomarginatus and Paraplea indistinguenda. In the paper he also reported the change of population density of Microvelia douglasi by the insecticide applications against rice stem borer. Ito et al. (1962) recorded Gerris Zacustris latiabdominis (G. lacustris latabdominalis), Gerris (Aquarius) paluduminsularis (Aquarius paludum), Microvelia douglasi and Hydrometra sp. from paddy fields in Japan, and observed the first species attacks the rice stem borer larvae and the third one plant-and leafhoppers. Fernando (1963) mentioned that the following species were common in paddy fields near Nugegoda, Sri Lanka. They are Microvelia longicornis, Micronecta quadristrigata, M. flavus, $M$. punctinotum, M. siva, M. fascioclavus and Anisops nivea. Fernando and Leong (1963) recorded Anisops kuroiwae (A. batillifrons) from paddy fields in Sri Lanka. Lansbury (1964) recorded Anisops breddini collected from shallow large muddy pools on uncultivated rice fields of Viet Nam. Miyamoto (1964a) recorded two Microvelia species, douglasi and morimotoi, from paddy fields in the Nansei Is. Miyamoto (1964b) also recorded six aquatic species from paddy fields in the Nansei Is. They are Saldoida armata, Mesovelia vittigera (M. orientalis), $\mathbf{M}$. japonica, Limnogonus (L.) fossarum, Hydrometra annamana and H. yasumatsui. Three females and one nymph of Saldoida armata among them were collected under stone in dried paddy field. Miyamoto (1965a) illustrated and mentioned that 15 species belonging to Saldidae (1 sp.), Hebridae (1 sp.), Hydrometridae (3 spp.), Veliidae (3 spp.), Gerridae (3 spp.), Belostomatidae (2 spp.), Notonectidae (1 sp.) and Corixidae (1 sp.) are found on or in paddy water in Japan. No collecting data, however, are presented for these species. Miyamoto (1965b) gave a note on the Japanese Micronecta, and mentioned that 3 species, sedula, sahlbergi and orientalis, dwell in paddy fields, but no data were given. Fernando (1965) mentioned that Tropocorixa pruthiana and Micronecta quadristrigata occur in paddy fields in 


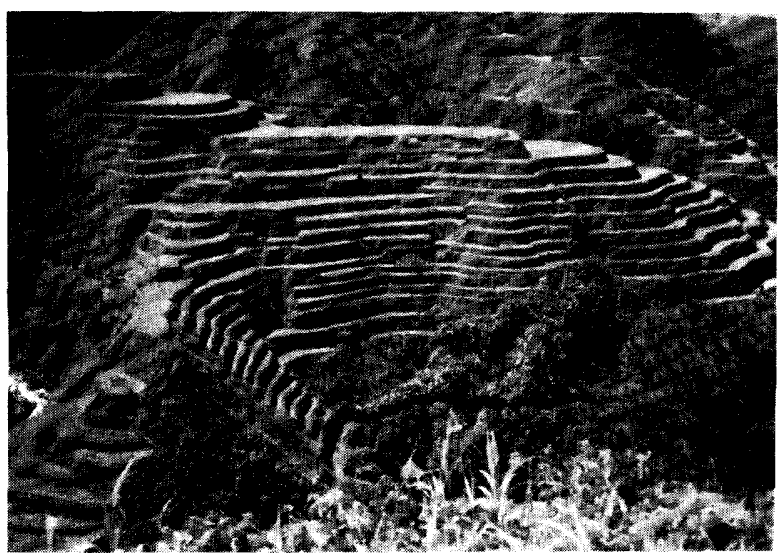

Fig. 1. Rice terraces of Banaue, Ifugao, Luzon. July 28, 1979.

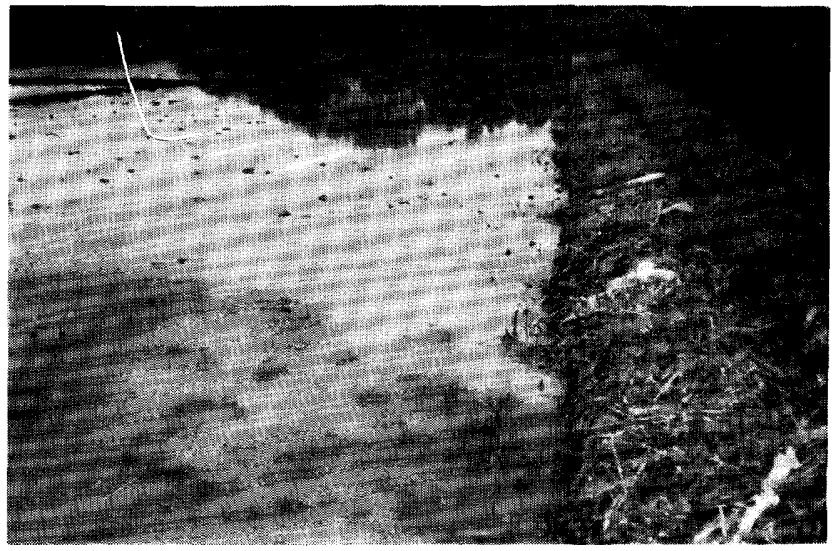

Fig. 2. Paddy field of Tugbok, Davao City, Mindanao, where collectings o aqua tic insects were made. August 30, 1979.

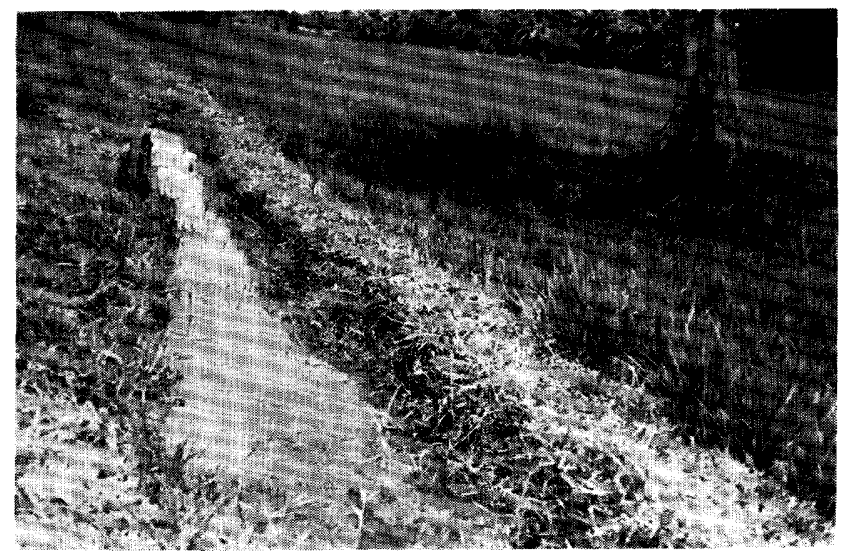

Fig. 3. Paddy field and irrigation ditch of Bislig, Surigao del Sur, Mindanao, where collectings of aquatic insects were made. September 4, 1979. 
Table 1. Former records on the aquatic and semiaquatic Heteroptera from paddy water in the world ${ }^{1}$.

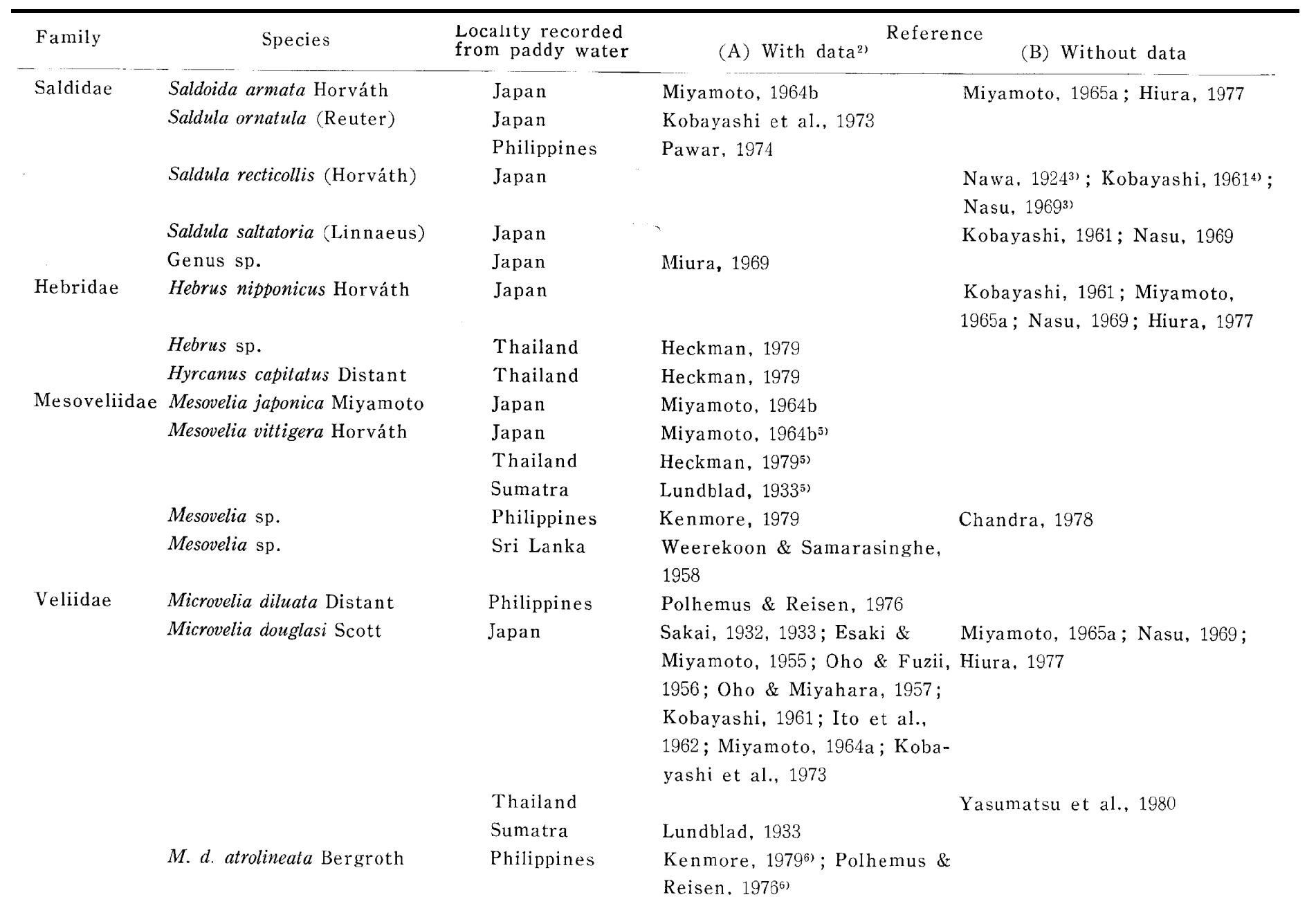




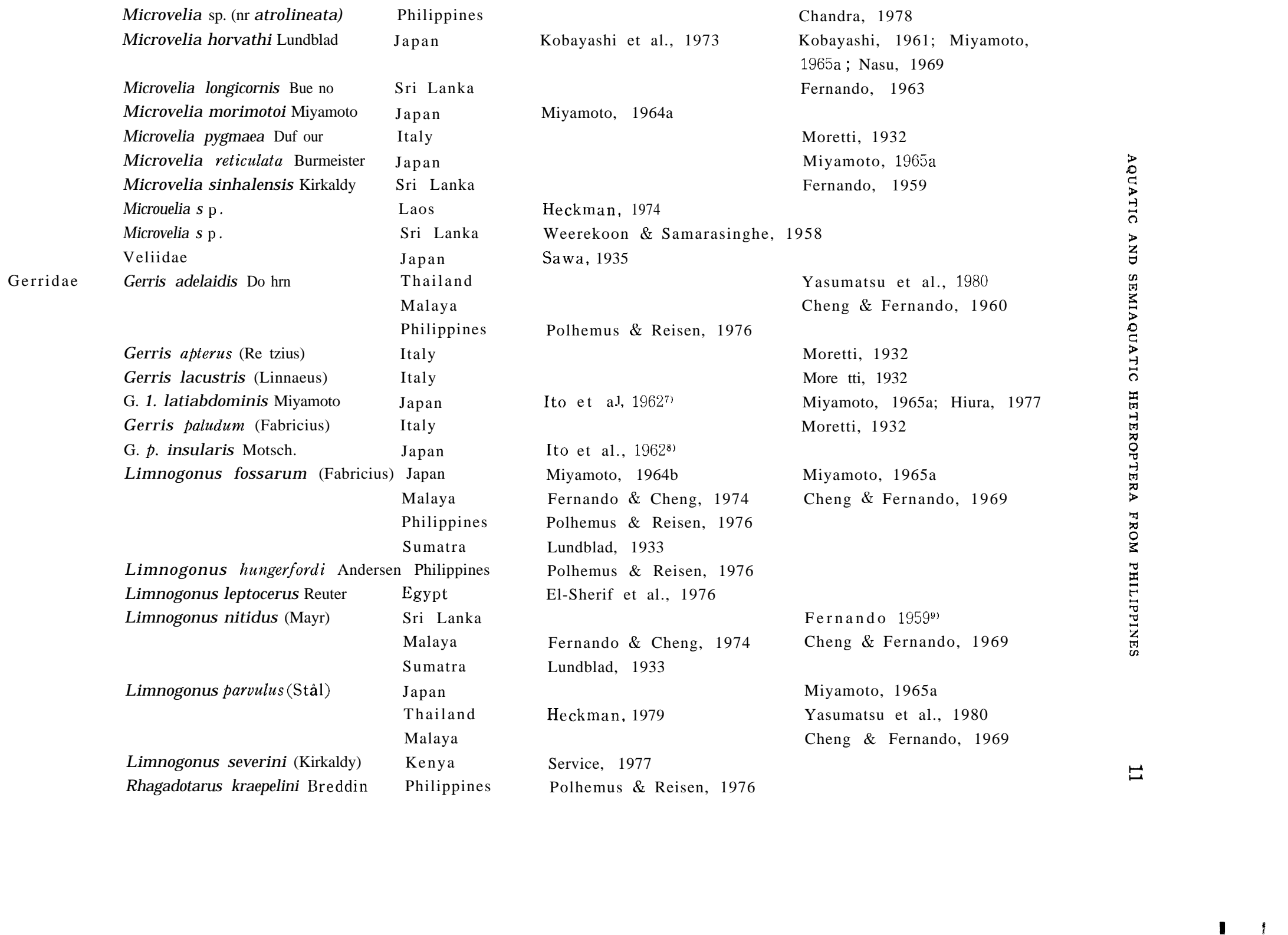


Tenagogonus (Limnometra) sp.

Genus sp. 1

Genus sp. 2

Philippines

Laos

Laos

Hydrometridae Hydrometra ?aegyptica $\mathrm{H}$. et E. Kenya

Hydrometra albolineata Scott

Japan

Hydrometra annamana $\mathrm{H}$. et $\mathrm{E}$.

Hydrometra lineata Eschscholtz

Japan

Philippines

Philippines

Thailand

Hydrometra procera Horváth

Japan

Hydrometra stagnorum (Linnaeus)

Hydrometra yasumatsui Miyamoto

Hydrometra sp.

Hydrometra sp.

taly

Japan

Japan

Laos

Ochteridae Ochterus marginatus (Latreille)

o. m. flavomarginatus Scott

Philippines

Japan

Naucoridae Heleocoris bengalensis Montandon Sri Lanka Ilyocoris cimicoides (Linnaeus)

China

Italy

Naucoris obscuratus kenyalis Poisson Kenya

Genus sp.

Laos

Pleidae
Hydrometra orientalis Lundblad

Polhemus \& Reisen, 1976

Heckman, 1974

Heckman, 1974

Service, 1977

Paraplea japonica (Horváth) Japan

Paraplea liturata (Fieber) Sumatra

Thailand

Paraplea quinquemaculata (Lundblad) Thailand

Paraplea sobrina (Stàl)

Philippines

Plea atomaria (Pallas)

Italy
Kobayashi et al., 1973

Miyamoto, 196 $₫$ b

Pawar, 1974'11) ; Polhemus \&

Reisen, 1976

Polhemus \& Reisen, 1976

Heckman, 1979

Miyamoto, 1964b

Ito et al., 1962

Heckman, 1974

Pawar, 1974

Esaki, 1941

Service, 1977

Heckman, 1974

Watanabe et al., 1968

Nawa, 192410) ; Kobayashi, 1961;

Miyamoto, 1965a; Nasu, 1969;

Hiura, 1977

Miyamoto, 1965a

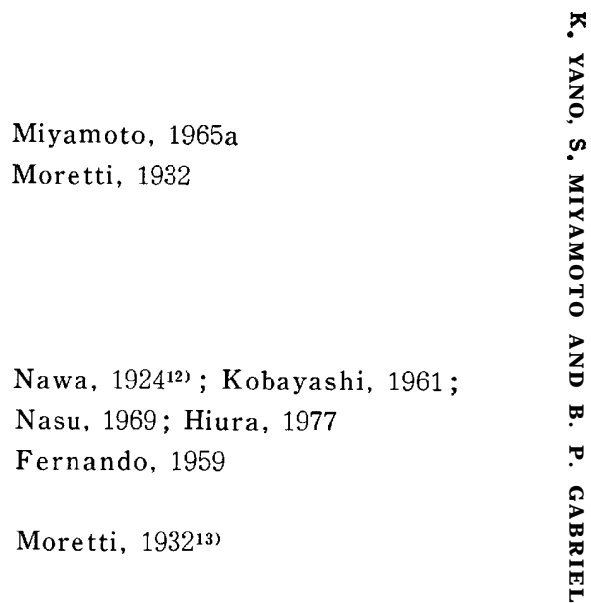

Nawa, 192414) ; Kobayashi, 1961 ; Nasu, 1969

Lundblad, 1933'

Heckman, 197916)

Heckman, 197917)

Polhemus \& Reisen, 1976 ${ }^{18}$ )

Moretti, $1932^{19}$ 
Anisops crinita Brooks Sri Lanka

Japan

Sri Lanka

Thailand

Anisops nivea (Fabricius)

Sri Lanka

Sumatra

Anisops nodulata Brooks

Philippines
Anisops ogasawarensis Matsumura Japan

Anisops philippinensis Brooks Philippines

Anisops sardea Herrich-Schäffer Egypt

Anisops sp. (? worthingtoni Jaczewski) Kenya

Anisops sp. $1 \quad$ Laos

Anisops sp. 2 Laos

Enithares genitalis Lundblad Java

Enithares mandalayensis Distant Thailand

Enithares sobria Stảl Kenya

Enithares uncata Lundbald Sumatra

Notonecta glauca Linnaeus Italy

Notonecta triguttata Motschulsky Japan

Notonectidae USA

Nepidae

Cercotmetus sp. Laos

Laccotrephes ater (Linnaeus) Kenya

Laccotrephes brachialis Gerstäcker Kenya

Laccotrephes fabricii Stål Kenya

Laccotrephes grossus (Fabricius) Laos

Sri Lanka

Laccotrephes japonensis Scott Japan
Heckman, 1974

Heckman, 1979

Lansbury, 1964

Fernando, 195920)

Miyamoto, 1965a

Pawar, 1974; Polhemus \&

Reisen, 197621)

Fernando \& Leong, 196321)

Heckman, 197921)

Lundblad, 1933

Brooks, 1951; Polhemus \&

Reisen, 1976

Fernando, 195921

Fernando, 1963

Hiura, 197722)

Polhemus \& Reisen, 1976

El-Sherif et al., 1976

Service, 1973

Heckman, 1974

Heckman, 1974

Lansbury. 1968

Heckman, 1979

Service, 1973

Lundblad, 1933

Watanabe et al., 1968

Lange et al., 1970

Heckman, 1974

Service, 1977

Service, 1977

Service, 1973

Heckman, 197423)

Watanabe et al., 1968 
Laccotrephes maculata (Fabricius;) Sri Lanka

Laccotrephes robustus Stål Philippines

Thailand

Laccotrephes simulatus Montandon Sumatra

Laccotrephes sp.

Nepa rubra Linnaeus

Ranatra bottegoi Montandon

Ranatra chinensis Mayr

Ranatra diminuta Montandon

Ranatra elongata Dohrn

Ranatra linearis (Linnaeus)

Ranatra longipes Stål

Ranatra sordidula Dohrn

Ranatra unicolor Scott

Ranatra varipes Stål

Ranatra vicina Signoret

Ranatra sp.

Ranatra sp.

Ranatra sp.

Belostomatidae Diplonychus grassei (Poisson.)

Diplonychus japonicus (Vuillefro

Diplonychus major Esaki

Diplonychus molestus (Dufour)

Diplonychus rusticus (Fabricius)

Diplonychus sp.

Lethocerus deyrollei (Vuillefroy)
Kenya

Argentina

Italy

Kenya

Japan

Philippines

Sri Lanka

Italy

Malaya

Sri Lanka

China

Thailand

Egypt

Philippines

Laos

Sri Lanka

Kenya

Japan

China

Japan

Malaya

Philippines

Sri Lanka

Sumatra

Thailand

Egypt

Sri Lanka

Japan
Polhemus \& Reisen, 1976

Fernando, 1959

Heckman, 1979

Lundblad, 1933

Service, 1977

Ito, 191824)

Service, 1977

Watanabe et al., 1968

Polhemus \& Reisen, 1976

Fernando, 1959

Moretti, 1932

Fernando \& Cheng, 1974

Fernando, 1959

Esaki, 1941

Heckman, 1979

El-Sherif et al., 1976

Polhemus \& Reisen, 1976

Heckman, 1974

Weerekoon \& Samarasinghe, 1958

Servive, 197726)

Esaki, 1941

Miyamoto, 1965a; Hiura, 1977

Hiura, 1977

Fernando \& Cheng, 197427)

Pawar, 1974; Polhemus \&

Reisen, 1976

Lundblad, 193328)

Fernando, 195928), 196128)

Heckman, 197928

El-Sherif et al., 1976 29

Weerekoon \& Samarasinghe, $1958^{30}$

Nawa, 1924; Yago, 194331) ; 


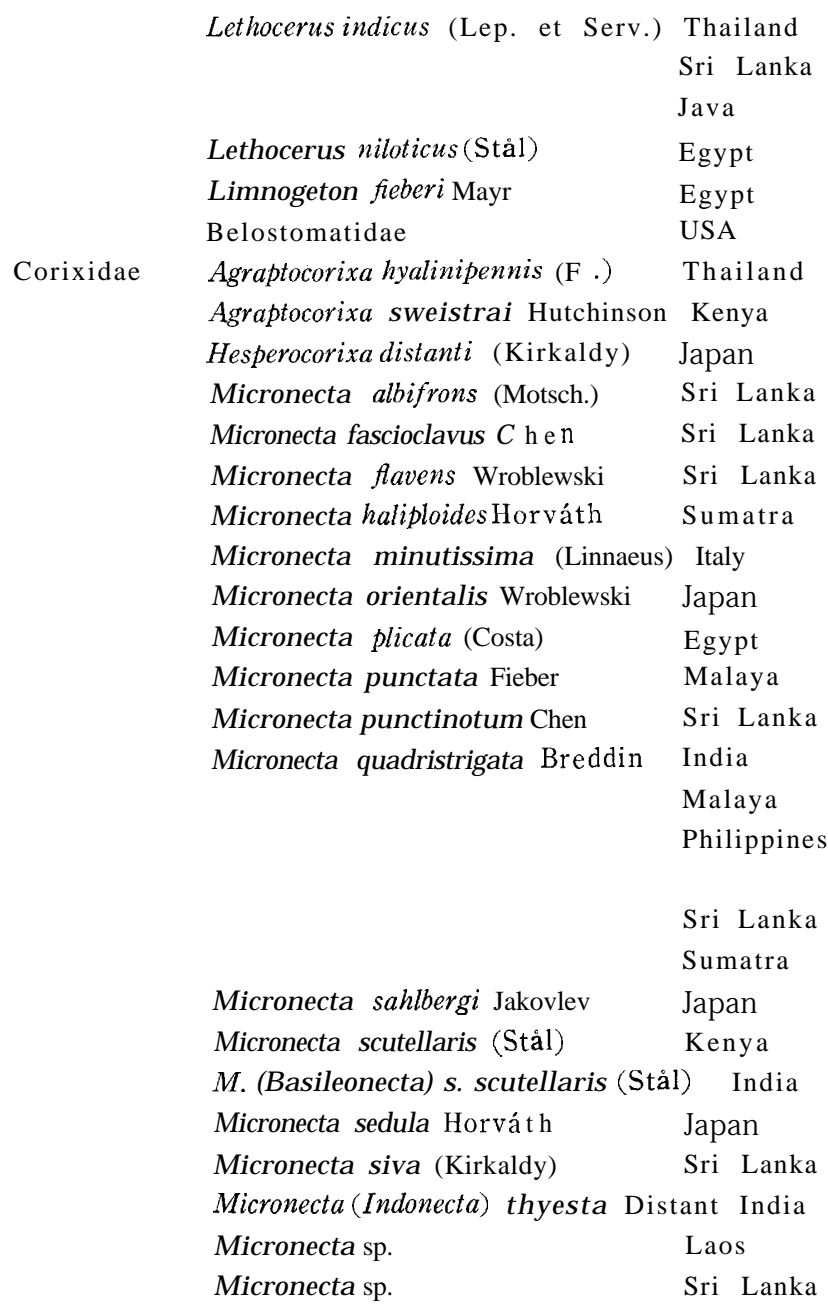

Heckman, 1979

Lundblad, 1933

El-Sherif et al., 1976

El-Sherif et al., 1976

Heckman, 1979

Service, 1973

Lange et al., 1970

Hiura, 1977

Fernando, 1959

Fernando, 1963

Fernando, 1963

Lundblad, 1933

El-Sherif et al., 1976

Miyamoto, 1965b

Fernando \& Cheng, 1974

Fernando, 1963

Fernando \& Cheng, 1974

Hutchinson, 1940 ${ }^{34)}$

Pawar, 1974; Polhemus \&

Reisen, 1976

Lundblad, 1933

Service, 1977

Hutchinson, 1940

Fernando, 195935), 1963, 1965

Miyamoto, 1965b

Miyamoto, 1965a, b; Hiura, 1977

Fernando, 1963

Hutchinson, 1940

Heckman, 1974

Weerekoon \& Samarasinghe, 1958 


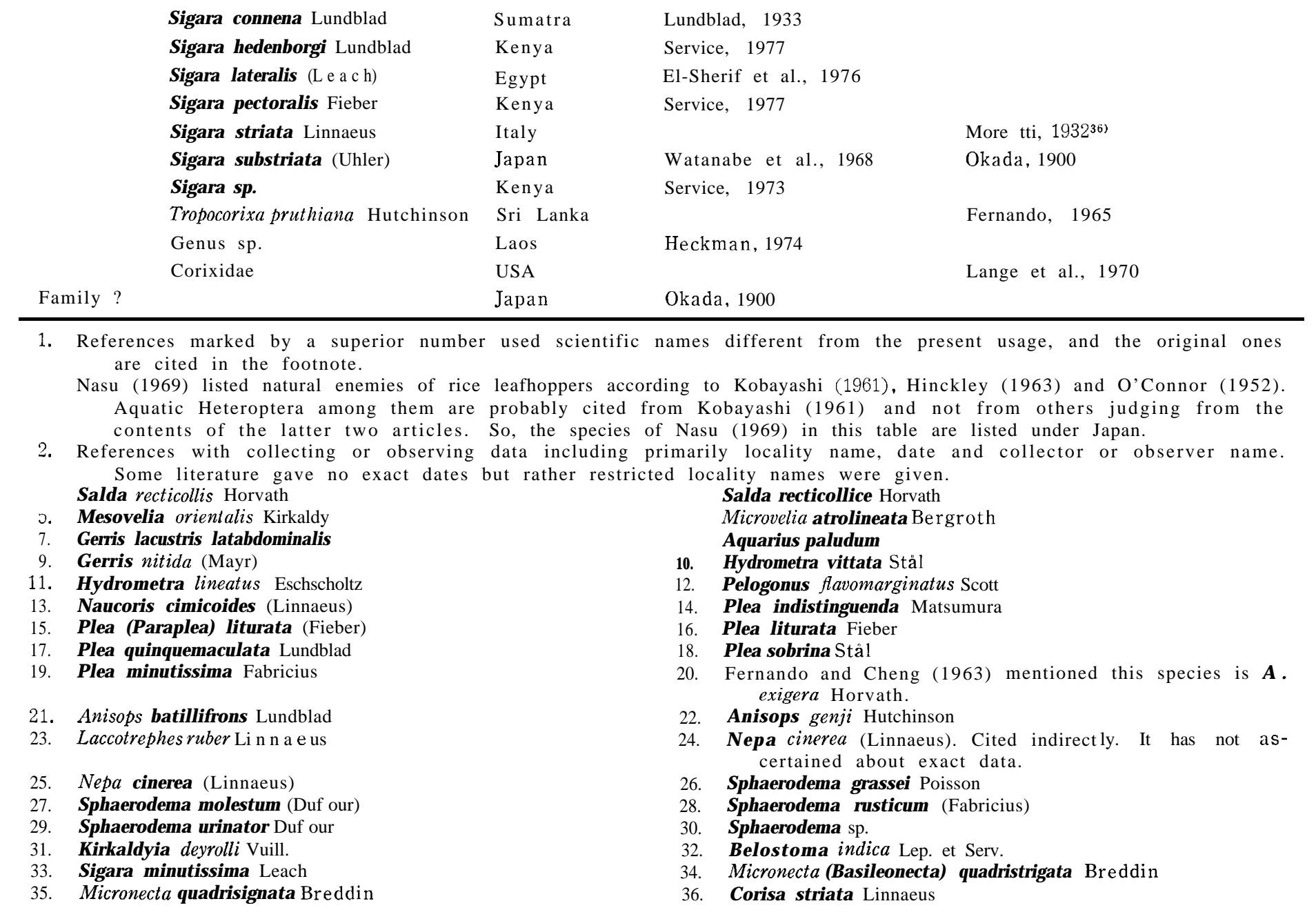


Sri Lanka. Watanabe et al. (1968) surveyed on the natural enemies of Culex tritaeniorhynchus summorosus of paddy field in Okayama, Japan. They collected adults and nymphs of the following 5 species of 4 families: Ranatra chinensis, Laccotrephes japonensis, Notonecta triguttata, Paraplea japonica and Sigara substriata. These authors checked the feeding of these species by giving larvae of Culex tritaeniorhynchus summorosus and found Notonecta triguttata, Ranatra chinensis and Laccotrephes japonensis are active in feeding the larvae, and Paraplea japonica and Sigara substriata are not active. Lansbury (1968) recorded 6 specimens of Enithares genitalis collected from paddy fields near Bogor, Java. Cheng and Fernando (1969) noted the occurrence of 4 Gerrid species from Malayan paddy fields. These are Limnogonus fossarum, L, parvulus, L. nitidus and Gerris adelaidis. Miura (1969) collected 3 specimens of a species of Saldidae by sweeping nurseries in Matsue, Japan. Nasu (1969) cited 8 species of aquatic Heteroptera predaceous to rice leafhoppers based on the record of Kobayashi (1961).

1970-1980. Lange et al (1970) mentioned the occurrence of Belostomatidae, Notonectidae and Corixidae in paddy fields of California. They stated that the Corixidae cause some damage to rice seedlings. Service $(1973,1977)$ made researches on the mortalities of the larvae of Anopheles gambiae complex in Kenya, and used 17 species including 3 unidentified species of aquatic Heteroptera dwelling in paddy fields for it. These species are Hydrometra ? aegyptica, Limnogonus severini, Micronecta scutellaris, Sigara hedenborgi, S. pectoralis, Sigara spp., Agraptocorixa sweistrai, Laccotrephes brachialis, L. ater, L. fabricii, L. sp., Ranatra bottegoi, Diplonychus grassei (Sphaerodema grassei), Anisops sp. (? worthingtoni), Enithares sobira and Naucoris obscuratus kenyalis. Kobayashi et al. (1973) collected the paddy dwelling insects in Tokushima, Japan, and listed the following 4 aquatic Heteroptera: Hydrometra albolineata, Microuelia douglasi, M. horvathi and Saldula ornatula. Pawar (1974, mimeographed) presented a terminal paper to IRRI on the insects of rice in the Philippines. He listed 6 species of aquatic Heteroptera collected from paddy fields. They are Micronecta quadristrigata, Saldula ornatula, Hydrometra lineata (H. Zineatus), Ochterus marginatus, Diplonychus rusticus (D. rusticum) and Anisops kuroiwae (A. kuroiwai). Pawar listed one more species, Lethocerus indicus, which was collected by light trap in paddy field. Heckman (1974) studied on the seasonal succession of species in a paddy field in Laos. He observed 14 aquatic Heteroptera including 12 unidentified species. Fernando and Cheng (1974) stated in their paper on the aquatic Hemiptera in Malaya and Singapore that 6 species of 4 families were found in Malayan paddy fields. They are Limnogonus fossarum, L. nitidus, Ranatra longipes, $D i$ plonychus molestus (Sphaerodema molestum), Micronecta quadristrigata and M. punctata. Locality names in Malaya were given for the first 4 species and no data were presented for the last 2 species. El-Sherif et al. (1976) made surveys on aquatic insects of rice nurseries and paddy fields in Egypt, and collected the following species of Heteroptera. They are Limnogonus leptocerus, M icronecta plicata, Sigara lateralis, Ranatra vicina, Lethocerus niloticus, Limnogeton fieberi, Diplonychus urinator (Sphaerodema urinator) and Anisops sardea. According to them, Micronecta plicata, Diplonychus urinator (S. urinator) and Anisops sardea are rather common among these species concerned. Polhemus and Reisen (1976) reported the aquatic Hemiptera of the Philippines mainly based on the material collected from the Luzon and some from other islands. Among the species reported, 17 species and 1 unidentified species belonging to 8 families were collected from paddy fields including adjoining irrigation ditches. Hiura (1977) stated in a colored illustration book that 13 species of aquatic Heteroptera are seen in paddy fields of Japan, but no collecting data are available. These 13 species are same to those of Miyamoto (1965a) except for 5 species, Hesperocorixadistanti, O chterus marginatus flavomarginatus, Laccotrephes japonensis, Diplonychus major and Anisops ogasawarensis (A. genji). In 1978. Chandra reported that Microvelia sp. nr atrolineata and Mesovelia sp. attack the rice leaf- and planthopppers in the Philippines. Kenmore (1979, mimeographed) mentioned that Microvelia douglasi atrolineata (M. atrolineata) is a predator of the brown planthopper, white backed planthopper, and rice green leafhopper, and M esovelia 
Table 2. Known prey records of aquatic and semiaquatic Heteroptera from paddy water of the world*.

\begin{tabular}{|c|c|c|c|c|}
\hline Family & Predaceous species & Prey insect recorded & Locality recorde & Reference \\
\hline \multirow[t]{2}{*}{ Saldidae } & Saldula recticollis (Horváth) & planthoppers & Japan & Nawa, 1924 \\
\hline & Saldula saltatoria (Linnaeus) & plant- and leafhoppers & Japan & Kobayashi, 1961 \\
\hline Hebridae & Hebrus nipponicus Horvát h & plant- and leafhoppers & Japan & Kobayashi. 1961 \\
\hline \multirow[t]{2}{*}{ Mesoveliidae } & Mesovelia $s \mathrm{p}$ & plant- and leafhoppers & Philippines & Chandra, 1978 \\
\hline & & Nilaparvata lugens (Stål) & Philippines & Kenmore, 1979 \\
\hline \multirow[t]{9}{*}{ Veliidae } & Microvelia douglasi Scott & leafhoppers & Japan & $\begin{array}{l}\text { Sakai, 1932, 1933; Kobayashi, 1961; } \\
\text { Ito et al., } 1962\end{array}$ \\
\hline & & planthoppers & Japan & Kobayashi, 1961; Ito et al., 1962 \\
\hline & & plant- and leafhoppers & Thailand & Yasumatsu et al., 1980 \\
\hline & & Recilia dorsalis Motschulsky & Japan & Esaki \& Miyamoto, 1955 \\
\hline & & Nephotettix cincticeps Uhler & Japan & Oho \& Miyahara, 1957 \\
\hline & M. d. atrolineata Bergroth & Nilaparvata lugens(Stål) & Philippines & Kenmore, 1979 \\
\hline & & Sogatella furcifera Horváth & Philippines & Kenmore, 1979 \\
\hline & & Nephotettix cincticeps Uhler & Philippines & Kenmore, 1979 \\
\hline & Microvelia sp. (nr atrolineata) & plant- and leafhoppers & Philippines & Chandra, 1978 \\
\hline \multirow[t]{3}{*}{ Gerridae } & Gerris adelaidis Do $\mathrm{hrn}$ & plant- and leafhoppers & Thailand & Yasumatsu et al., $\mathbf{1 9 8 0}$ \\
\hline & Gerris lacustris latiabdominis Miyamoto & Chilo suppressalis Walker & Japan & Ito et al., 1962 \\
\hline & Limnogonus parvulus (Stål) & plant- and leafhoppers & Thailand & Yasumatsu et al., $\mathbf{1 9 8 0}$ \\
\hline \multirow[t]{2}{*}{ Hydrome tridae } & Hydrometra albolineata Scott & planthoppers & Japan & Nawa, 1924 \\
\hline & & plant- and leafhoppers & Japan & Kobayashi, 1961 \\
\hline \multirow[t]{2}{*}{ Ochteridae } & Ochterus marginatus flavomarginatus & Scott planthoppers & Japan & Nawa, 1924; Kobayashi, 1961 \\
\hline & & leafhoppers & Japan & Kobayashi, 1961 \\
\hline \multirow[t]{2}{*}{ Pleidae } & Paraplea indistinguenda (Matsumura) & planthoppers & Japan & Nawa, 1924; Kobayashi, 1961 \\
\hline & & leafhoppers & Japan & Kobayashi, 1961 \\
\hline \multirow[t]{2}{*}{ Corixidae } & Sigara substriata (Uhler) & planthoppers & Japan & Okada, 1900 \\
\hline & Micronecta quadristrigata Breddin & midge larva & Philippines & Pawar, 1974 \\
\hline Family ? & Genus sp. & planthoppers & Japan & Okada, 1900 \\
\hline
\end{tabular}

* Scientific names of this table are present usage and the original ones are referable to the footnotes of Table 1 . 
sp. is also predaceous to the brown planthopper in the Philippines. Heckman (1979) reported the occurrence of 15 aquatic Heteroptera in northern Thailand. These species belong to Hebridae (2 spp.), Mesoveliidae (1 sp.), Hydrometridae (1 sp.), Gerridae (1 sp.), Corixidae (1 sp.), Nepidae (2 spp.), Belostomatidae (2 spp.), Notonectidae (3 spp.), and Pleidae (2 spp.). Yasumatsu et al. (1980, mimeographed) listed Microvelia douglasi, Gerris adelaidis and Limnogonus parvulus as nymphal or adult predators of plant- and leafhoppers in Thailand.

One hundred and fourteen species and five subspecies belonging to 13 families including species without no definite data and excluding unidentified ones have been recorded from paddy water in the world. Dominant families may be Corixidae, Nepidae, Notonectidae, Belostomatidae, Gerridae, Veliidae and Hydrometridae among the families concerned. Most species were recorded without any biological informations such as food habits, seasonal abundance, and so on. About ten species have been reported with their food habit as shown in Table 2. It is apparent that very limited species are reported with their exact host species compared with the known species. Host insects recorded are mostly plant- and leafhoppers except for two cases of rice stem borer and midge larva. Only 6 species of host have been recorded by their specific names for 4 predaceous species. Host insects reported under the name of plant- and/ or leafhoppers without giving specific name are required to be checked for its exact host name. Other insect and animal groups which have not recorded before are also attacked by aquatic Heteroptera in paddy ecosystem (Yano, unpublished data), but it has not been reported so far as we are aware. Apart from paddy water, however, these aquatic Heteroptera have been reported to attack various organisms. Further studies on their food habits may probably make their status in biological control in paddy field ecosystem more clear. It may also reveal the habit attacking other predaceous species as seen in other environment (Riley, 1922).

Two species, Nepa rubra and Lethocerus deylollei, have been reported to be injurious to rice plant as cited above. Some damage by the Corixidae have been reported also (Lange et al., 1970) but it is not serious. Only three families, Nepidae, Belostomatidae and Corixidae among the all families recorded from paddy fields include some species injurious to rice seedlings. It is consequently noted here that the aquatic Heteroptera in paddy fields are negligible as pest insects of rice. It is obvious that the expected figure of paddy dwelling species in each country is bigger than that of the known data. These figures, known or expected, are too big to neglect their presence in the paddy field ecosystem. Faunal and biological studies on the group are thus expected. 


\section{Species collected in the Philippines with descriptions of new species}

A total of 717 specimens of 17 species belonging to 11 families were collected and enumerated in the following lines. All specimens were collected by the first author, and from paddy water unless otherwise stated. Among the material collected by sweep net made above water level in Pila, Laguna, 2 specimens of the family Ochteridae were found and included here, Eight specimens of Saldoida armata Horvath collected by Dr. K. Morimoto from levee by paddy field of Banaue were included here also through his courtesy. The material collected from irrigation ditch water by paddy field in Bislig, Mindanao, are also included here with indication of irrigation ditch. Locality based on the paddy water material is shown with an asterisk. All measurements in the descriptions of new species are in $\mathrm{mm}$.

\section{SALDIDAE}

Saldoida armata Horvath

Specimens examined: 4 adults, 4 nymphs, Banaue, Ifugao, 27-31. vii. 1979, K. Morimoto, levee by paddy field.

Distribution: Philippines*, Japan, Nansei Is., Taiwan, India.

These specimens were collected at levee by paddy field which contained water.

HEBRIDAE

Hebrus bergrothi Horvath (Fig. 11)

Specimen examined: 1 adult, Banaue, Ifugao, 1. viii. 1979.

Distribution: Philippines* (endemic).

This is the first record from paddy water of the world and the first record of the family Hebridae from the Philippine paddy water.

\section{MESOVELIIDAE}

Mesovelia vittigera Horvath (Fig. 12)

Specimens examined: 24 adults, 13 nymphs, Tugbok, Davao City, 28-30. viii. 1979. 2 adults, Bislig, Surigao del Sur, 1-4. ix. 1979.

Distribution: Philippines*, Taiwan, Japan*, Nansei Is., Sumatra*, Thailand*, Korea, India, S. E. Asia, New Guinea, Guam, Middle East, S. Europe, Africa.

This is the species formerly known as M.orientalis Kirkaldy in Japan and its adjacent territories. It is not certain that an unidentified species of Mesovelia recorded by Chandra (1978) and Kenmore (1979) from the Philippines are identical with this species or not. This species seems to be common in the Philippine paddy water.

\section{VELIIDAE}

Microvelia douglasi atrolineata Bergroth, stat. nov. (Figs. 5, 6, 13)

SPecimens examined: 140 adults, 60 nymphs, Bay, Laguna, 14. viii. 1979. 1 adult, 15 nymphs, Tugbok, Davao City, 28-30. viii. 1979. 3 adults, 8 nymphs, Bislig, Surigao del Sur, 1-4. ix. 1979.

Distribution: Philippines*.

Polhemus and Reisen (1976) separated atrolineata from douglasi by the coloration and a lateral compression of the female abdomen. But douglasi (Fig. 4) is grayish as well as 


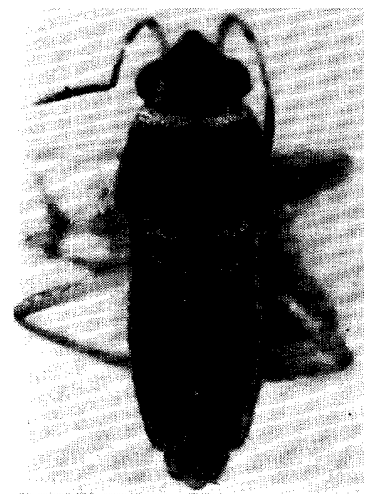

Fig. 4. Microvelia douglasi, $\widehat{\jmath}$. Fukuoka, Japan.
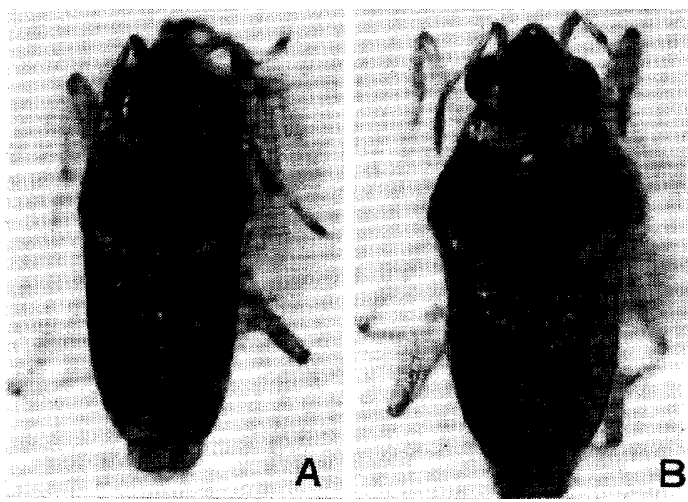

Fig. 5. Microvelia douglasi atrolineata. A : $\gtrsim$, Bay, Laguna. B: 古, same data.

brown in coloration, and the former colour is dominant, and some specimens of atrolineata are quite brown-coloured. Lateral compression at the base of female abdomen may be a good character for atrolineata, but sometimes Japanese douglasi also shows the same tende ncy. Male genital segments and parameres of the two forms are seen in the Figures 6-8. According to the Lundblad's system of douglasi (1933: 347-357), these differences may be within a range of species. General shape of atrolineata is rather shorter and broader than in douglasi.
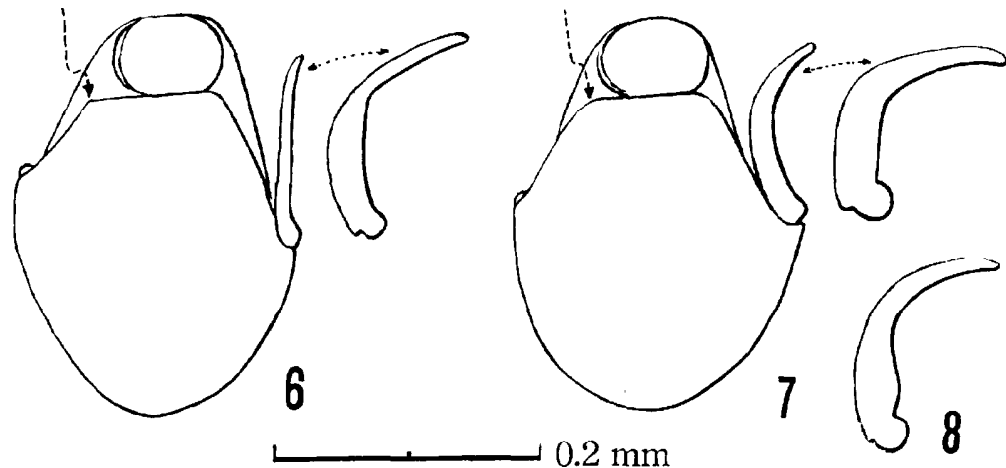

Figs. 6-8. Microvelia douglasi atrolineata, from Laguna, Philippines (6) and M. douglasi, from Fukuoka, Japan (7 and 8). 6, 7: Apical segments of abdomens, in ventral view, of respective forms, accompanying with right-hand parameres. a : Right-hand parameres of another specimen of douglasi.

Many specimens including immature stages were collected at Bay. It is obvious that this is one of the most common species with numerous individuals among the paddy dwelling aquatic Heteroptera in the Philippines. It may be due to the different condition of paddy water that less specimens were collected at Tugbok and Bislig. The water at Tugbok was then flowing into the paddy fields where collectings were made and time had not been passed from the water was let in. The paddy water at Bislig was not enough but extremely limited into tiny spot. It is unknown, however, why no specimens were collected from Banaue. M. diluta Distant was recorded by Polhemus and Reisen (1976) from Lubang Island, but no specimens were collected by the present survey. 


\section{GERRIDAE}

Limnogonus fossarum (Fabricius) (Fig. 14)

Specimens examined: 1 adult, Banaue, Ifugao, 1 . viii. 1979. 1 adult, Tugbok, Davao City, 28-30. viii. 1979. 2 adults, Bislig, Surigao del Sur, 1-4. ix. 1979, irrigation ditch.

D istribution: Japan, Nansei Is*., Taiwan, China, Philippines*, Malaya*, Singapore, Celebes, Java, Sumatra*, Sri Lanka, India, Micronesia, Fiji.

This species is distributed up to the Nansei Islands, Japan. Five specimens were collected previously from paddy water of Ishigaki I., Nansei Is. Cheng and Fernando (1969) mentioned that this is the commonest and most widespread among Malayan Gerridae. They examined 2 specimens from Malayan paddy fields, and many from other aquatic habitats.

Limnogonus nitidus (Mayr) (Fig. 15)

S pecimens Examined: 15 adults, 4 nymphs, Tugbok, Davao City, 28-30. viii. 1979. 3 nymphs, Bislig, Surigao del Sur, 1-4. ix. 1979. 16 adults, ditto, 1-4. ix. 1979, irrigation ditch.

Distribution : Philippines*, Malaya*, Singapore, Sri Lanka*, India, Burma, Java, Sumatra*.

Cheng and Fernando (1969) noted this species is the least common of Limnogonus species in Malaya, occurring only in paddy fields and temporary pools. Judging from the present collection, this species may be distributed throughout the Philippine paddy fields of the plain area

Limnogonus parvulus (Stål) (Fig. 16)

SPeCimens EXAMINED: 4 adults, Banaue, Ifugao, 27-31. vii. 1979. 16 adults, ditto, 1. viii. 1979.

D istribution : Philippines*, Japan*, Nansei Is., Thailand*, Malaya, Singapore, Sri Lanka, China, India, Java, Arabia.

This species was not collected from plain areas of Luzon and Mindanao where the following species was collected. So far as the present knowledge is concerned, however, this species seems to be distributed most widely in S. E. Asian paddy water among the known species of this family.

\section{HYDROMETRIDAE}

Hydrometra lineata Eschscholtz (Fig. 17)

Specimens EXAmined: 1 adult, Banaue, Ifugao, 1. viii. 1979. 19 adults, Tugbok, Davao City, 28-30. viii. 1979. 1 adult, Bislig, Surigao del Sur, 1--1. ix. 1979. 2 adults, ditto, 1-4. ix. 1979, irrigation ditch.

Distribution : Philippines*, Java, Sumatra, Malaya, Sri Lanka.

Most specimens of the present material were collected from Tugbok. These individuals were found associating with debris on water surface or near levee.

Hydrometra orientalis Lundblad (Fig. 18)

S Pecimens examined: 7 adults, Tugbok, Davao City, 28-30. viii. 1979. 5 adults, Bislig, Surigao del Sur, 1-4. ix. 1979, irrigation ditch.

Distribution: Philippines*, Sumatra, Java, Malaya, Burma, Thailand, Viet Nam.

\section{OCHTERIDAE}

Ochterus marginatus (Latreille) (Fig. 19)

Specimens examined: 2 adults, Pila, Laguna, 18 \& 21. viii. 1979, sweeping paddy field.

Distribution: Philippines*, Taiwan, China, India, Middle East, S. Europe, N. Africa.

These two specimens were collected by sweeping made above water level. Japanese subspecies, 0. marginatus flavomarginatus, is rather common around boundary between paddy water and levee. 
PLEIDAE

Paraplea davaoensis Miyamoto, sp. nov. (Figs. 9, 20, 21)

Size, female. Body length $1.70 \mathrm{~mm}$., greatest width across abdomen $0.93 \mathrm{~mm}$.

General colour brownish; head stramineous, somewhat brown centrally, without markings, with eyes reddish brown and rostrum dark brown; pronotum brownish, with anterior and lateral margins broadly, distinctly pale and posterior margin obscurely pale : the disc with one pair of dark brown spots and an additional one near anterior margin, one black spot near each humeral angle, and with a median black spot near posterior margin ; scutellum brown, with postero-lateral margins stramineous ; hemelytra brown with pale markings, each at base and center of corium and at center of clavus. Legs stramineous. -Body beneath dark brown.
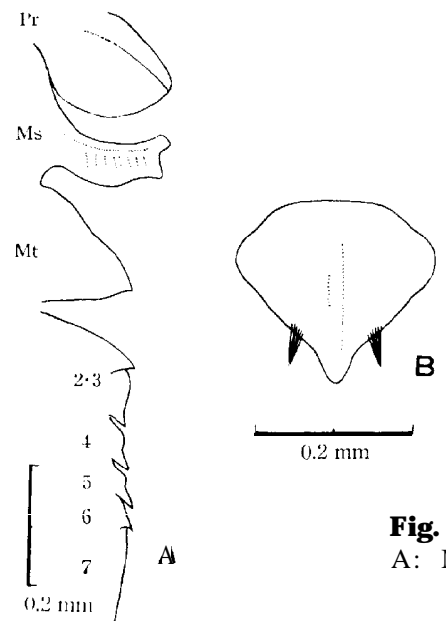

Fig. 9. Paraplea davaoensis, sp. nov. ㅇ․ A: Median sternal keels, lateral view. B : Subgenital plate.

Body shape ellipsoid; dorsal surface covered with distinct punctures, those on head and scutellum smaller than on the rest. Head, seen from above, short, about one sixth as long as wide (.13:.80), with the apical margin evenly rounded; in frontal view, head wider than tall $(.34: .80)$. Rostrum reaching apices of anterior coxae, with the apical segment slightly longer than the preceding (.12:.10). Pronotum, in median length, a little longer than half the width between humeri (.53:.93), with humeral angles rather prominent; lateral margins divergent; posterior margin convex, with median portion somewhat emarginate; scutellum shorter than wide $(.35: .50)$. Abdomen almost equal to length from head to scutellum, and widest at level of tip of scutellum.

Relative lengths of leg segments:

\begin{tabular}{lccc} 
& Femur & Tibia & \multicolumn{2}{c}{ Tarsus (tarsal segments } \\
combined together)
\end{tabular}

Median sternal keels of thorax and abdomen characteristic, and figured [Fig. 9-A) ; prosternal keel largest with ventral apex rounded; mesosternal keel nearly of equal width from near base to apex, with antero-ventral angle projected; metasternal keel triangular. Subgenital plate (operculum or seventh abdominal sternum) (Fig. 9-B) somewhat triangular, as wide as long (.25:.23), broadest before middle, with postero-lateral margins wavely sinuate and furnished with a tuft of hairs on each side near apex. 
Holotype female (Type No. 2236, Kyushu Univ.), Tugbok, Davao City, 28-30. viii. 1979, paddy water, K. Yano leg. The type is preserved in the Entomological Laboratory, Kyushu University.

The present species is easily separated from P. sobrina Stål, an only known species from the Philippines, in the smaller size, black spots on pronotum and peculiar structure of the sternal keels of thorax and abdomen, but davaoensis may be closely related to $\mathbf{P}$. Iiturata (Fieber), which is variable in size and colour pattern, but distinguished from the latter by the different structure of sternal keels of thorax and abdomen (compared with the Lundblad's drawings, 1933, fig. 42 on p. 133).

This is the first record of this family from the Philippine paddy water.

\section{NOTONECTIDAE}

Anisops kuroiwae Matsumura (Fig. 22)

S Pecimens EXAmined: 1 adult, 1 nymph, Bay, Laguna, 14. viii. 1979. 9 adults, 26 nymphs, Bislig, Surigao del Sur, 1-4. ix. 1979. 3 adults, ditto, 1-4. ix. 1979, irrigation ditch.

D istribution: Japan*, Nansei Is., Philippines*, Thailand*, Hainan Is., China, Taiwan, Burma, Assam, India.

This species was known as A. batillifrons Lundblad and seems to be distributed rather widely over Southeast Asian paddy water. It is a preliminary view that the species of this family will not be dominant at the starting period of paddy water ecosystem. Other groups on water surface dwellers such as Veliidae and Gerridae will be dominant from that time.

Anisops nodulata Brooks (Fig. 23)

Specimens EX Amined: : 1 adult, Banaue, Ifugao, 27-31. vii. 1979. 3 nymphs, ditto, 1. viii. 1979 .

Distribution : Philippines* (endemic).

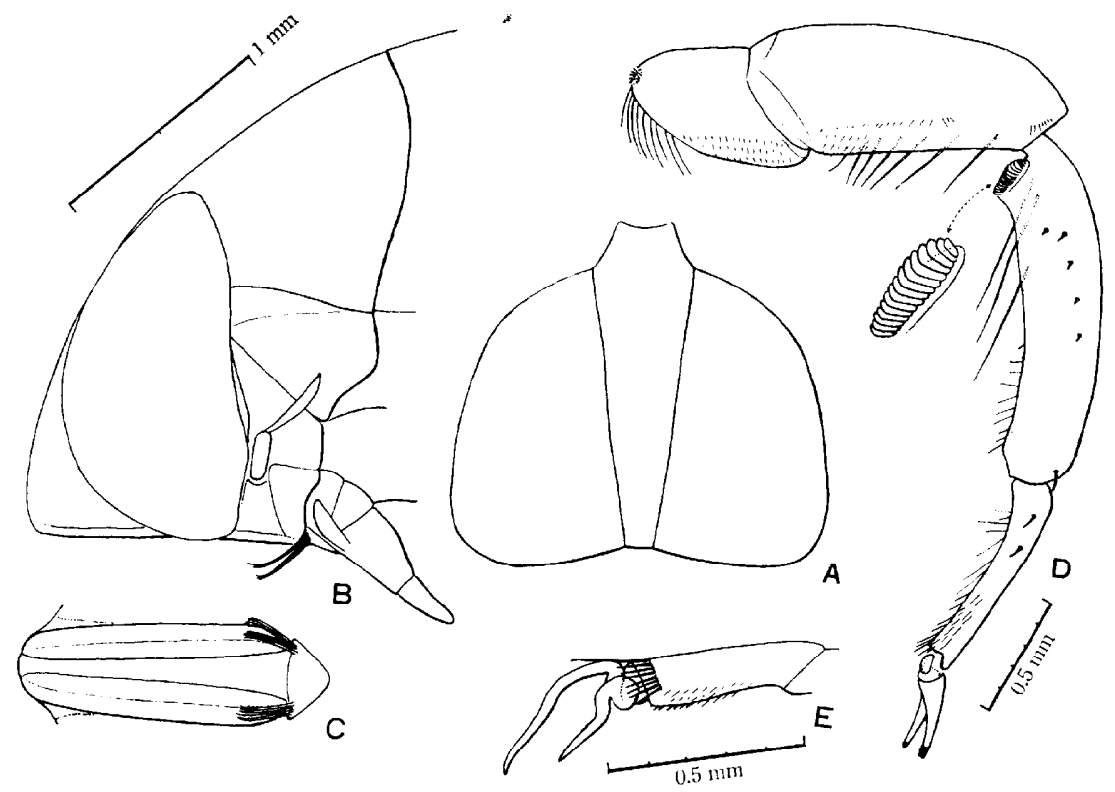

Fig. 10. Anisops yanoi, sp. nov. o. A: Head, oblique dorsal view to the body axis. B: Head with prothorax, lateral view. C: Frons, full view. D: Left-hand anterior leg, E: Apical segment with claws of left-hand middle leg. 
Anisops yanoi Miyamoto, sp. nov. (Figs. 10, 24)

Size. Males, length 7.3-7.5 mm., greatest width 1.9-2.0 mm ; females, length 6.8-7.2 mm., greatest width $2.0 \mathrm{~mm}$.

General colour somewhat stramineous. Eyes brown, anterior margin of vertex in male darkened, and antennae dark brown. Hemelytra hyaline and appearing stramineous towards base and gray near apex depending on the underlying body surface. Legs stramineous; all coxae widely dark brown; anterior femora with trochanters and middle femora broadly dark brown on dorsal surface, anterior tibiae each with a dark brown, distinct stria on dorsal side. Venter blackish brown with median keel and segmental margins of connexivum stramineous.

Male: Viewed from above, lateral outline of head rounded with vertex extending beyond anterior margins of eyes to form a short cephalic horn (Fig. 10) ; head about nine tenths as broad as pronotal humeral width (1.65:1.90) and almost four times the anterior width of vertex (1.65:.44); synthlipsis narrow, nearly one fourth the anterior width of vertex; head slightly less than pronotum in median length (.90:1.00). Pronotum approximately twice as wide as long (1.90: 1.00) ; lateral margins diverging and more than half the median length; posterior margin convex, medially emarginate. Frons medially sulcate throughout (Fig. 10-C) ; apex rounded viewed from above or below, but emarginate as seen obliquely to body axis; each side bordered by two carinae, the inner ones not meeting with each other. Labrum short, about twice as broad as long at base, apex rounded, and furnished with a tuft of long erect hairs near each basal corner (Figs. 10-B, C). Rostral prong (Fig. 10-B) shorter than the third rostral segment, with apex acute.

Stridulatory comb (Fig. 10-D) of about fifteen teeth, the second to sixth teeth somewhat larger than others. Middle tarsal claws (Fig. 10-E) strongly curved inwards at base, posterior claw much thicker but shorter than anterior one. Chaetotaxy of anterior leg as shown in Fig. 10-E, without large spines.

\begin{tabular}{|c|c|c|c|c|c|c|c|}
\hline & Femur & Tibia & & Tars. seg. & 1 & Tars. & seg. 2 \\
\hline Anterior leg & 1. 28 & 1.40 & & .80 & & & \\
\hline & (or 100 & $:$ & 109 & $:$ & 66 & 10 & -) \\
\hline Middle leg & $\begin{array}{l}2.48 \\
\text { (or } 100\end{array}$ & $\begin{array}{c}2.04 \\
:\end{array}$ & 82 & $\begin{array}{l}\text { 1. } 12 \\
:\end{array}$ & 45 & $\begin{array}{l}.40 \\
:\end{array}$ & 16) \\
\hline Posterior leg & 2.80 & 2. 20 & & .80 & & .80 & \\
\hline & (or 100 & : & 70 & : & 29 & : & 29) \\
\hline
\end{tabular}

Female: Viewed from above, outline of head rounded, nine tenths as broad as pronotal humeral width (1.65: 1.90) and about four times the anterior width of vertex (1.64: .40); synthlipsis less than one half the anterior width of vertex (.18:.40); head, along the median axis, about two thirds the pronotal length (.56:.81). Humeral width of pronotum slightly more than twice its median length $(1.90: .81)$; lateral margins divergent and slightly more than one half the median length: posterior margin convex, medially emarginate.

\begin{tabular}{|c|c|c|c|c|c|c|}
\hline \multicolumn{7}{|c|}{ Relative lengths of leg segments: } \\
\hline \multirow[b]{2}{*}{ Anterior leg } & Femur & Tibia & \multirow{2}{*}{\multicolumn{3}{|c|}{$\begin{array}{c}\text { Tars. seg. } 1 \\
.62\end{array}$}} & Tars. seg. 2 \\
\hline & 1. 12 & 1. 32 & & & & .40 \\
\hline \multirow{3}{*}{ Middle leg } & (or 100 & : & 118 & : & 54 & 36) \\
\hline & 2. 00 & 1.68 & & .86 & & .48 \\
\hline & (or 100 & : & 84 & : & 43 & $: \quad 24)$ \\
\hline \multirow[t]{2}{*}{ Posterior leg } & 2. 65 & 2.32 & & .80 & & .78 \\
\hline & (or 100 & : & 88 & : & 30 & : 29) \\
\hline
\end{tabular}


Holotype male (Type No. 2237, Kyushu Univ.), and 6 paratypes (1 male and 5 females), Banaue, Ifugao, 27-31. vii and 1. viii. 1979, all from paddy water, K. Yano leg. The holotype is preserved in the Entomological Laboratory, Kyushu University.

The combination of characters such as the grooved frons, a pair of tufts of long hairs on labrum and poorly developed chaetotaxy on the anterior legs of the male may be peculiar to the present species. Yanoi is superficially resembling to kuroiwae Matsumura (= batillifrons Lundblad) but easily separated by the more distinct coloration of legs, larger size of the body, entirely grooved frons, a pair of tufts of long hairs on labrum, different structure of stridulatory comb, chaetotaxy on anterior legs, and others.

Enithares martini Kirkaldy (Fig. 25)

Specimens examined: 2 adults, 2 nymphs, Banaue, Ifugao, 27 31. vii. 1979.

Distribution : Philippines* (endemic).

This is the first record of this genus from the Philippine paddy water.

BELOSTOMATIDAE

Lethocerus indicus (Lepeletier et Serville)

Specimens examined: 5 nymphs, Tugbok, Davao City, 28-30. viii. 1979.

Distribution : Philippines*, Thailand*, India, Sri Lanka*, China, Taiwan, Java*, Sumatra.

This species was formerly recorded from paddy water of Thailand. Pawar (1974) recorded this species from the Philippines based on the material collected at light in paddy fields.

\section{CORIXIDAE}

Micronecta quadristrigata Breddin (Fig. 26)

Specimens examined : : 1 adult, Tugbok, Davao City, 28-30. viii. 1979. 278 adults, 3 nymphs, Bislig, Surigao del Sur, 1-4. ix. 1979.

Distribution : Philippines*, Sri Lanka*, India*, Malaya, Sumatra*, Java, Celebes, Viet Nam, Thailand, Hong Kong, Taiwan, Iran.

This species is probably one of the most widely distributed and common species of the Corixidae in S. E. Asian aquatic habitats as well as Agraptocorixa hyalinipennis. Many specimens of this species were collected at Bislig from a small amount of water. Thus, it seems probable that this species is tolerable to a high population density.

From the Philippines, 18 species and 4 unidentified species belonging to 11 families have been known from paddy fields previously (cf. Table 1). This figure, however, contains the records of Polhemus and Reisen (1976) who mixed the data from paddy and irrigation ditch. Present records add 9 species (Saldoida armata, Hebrus bergrothi, Mesovelia vittigera, Limnogonus nitidus, Limnogonus parvulus, Paraplea davaoensis, Anisops yanoi, Enithares martini and Lethocerus indicus) and now total 27 species and 4 unidentified species of 12 families are known from the Philippine paddy water.

Some preliminary notes on the abundance of species concerned mentioned below are provided by the present knowledge which is certainly far from expected level. Following species seems to be major among the known species. They are Microvelia douglasi atrolineata, Micronecta quodristrigata and Anisops kuroiwae. Mesovelia vittigem, Limnogonus nitidus and Hydrometralineata may stand next.

Species of Naucoridae have not been recorded from the Philippine paddy water, though it is expected to be collected by the future surveys. 
AQUATICAND SEMIAQUATIC HETEROPTERA FROM PHILIPPINES

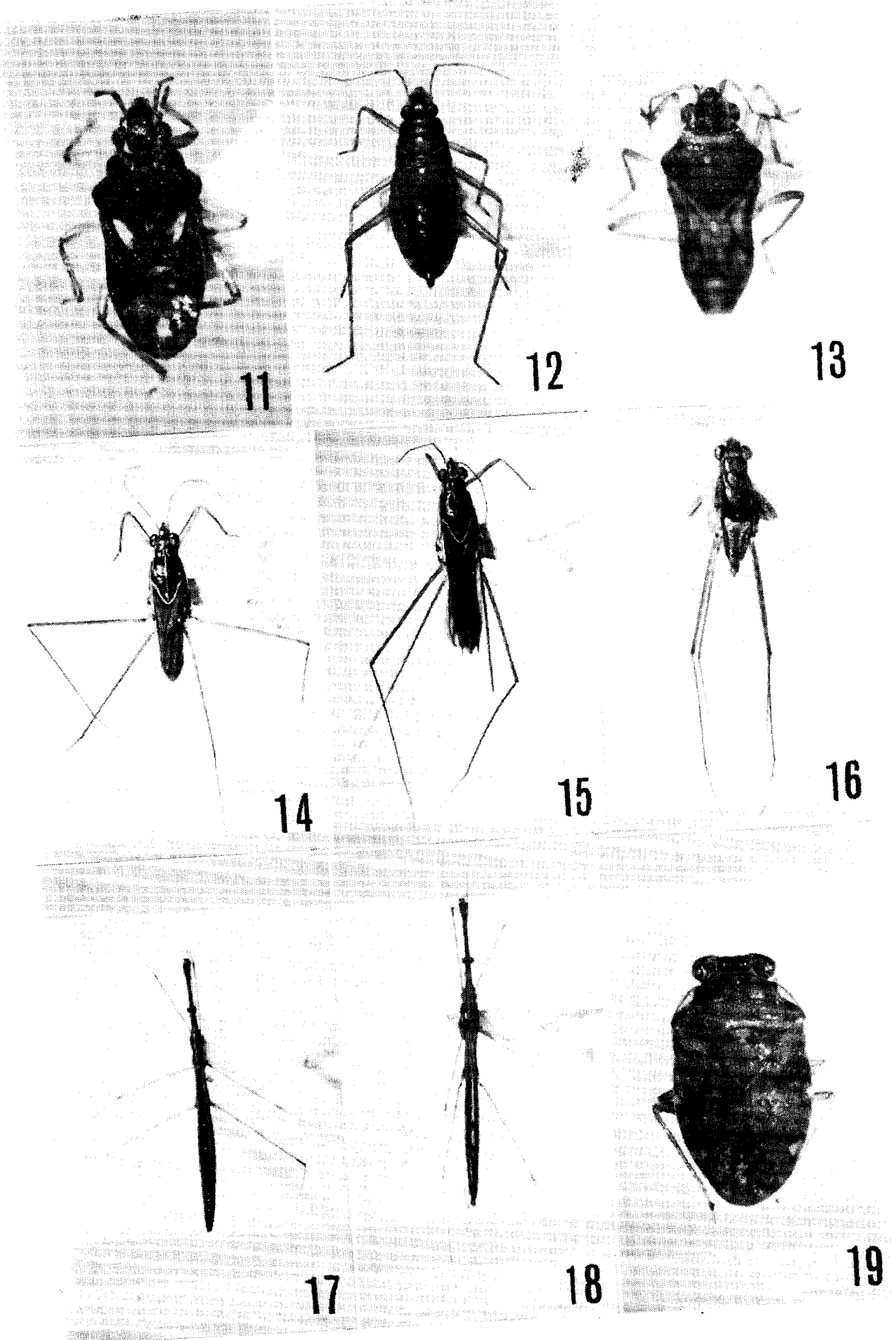



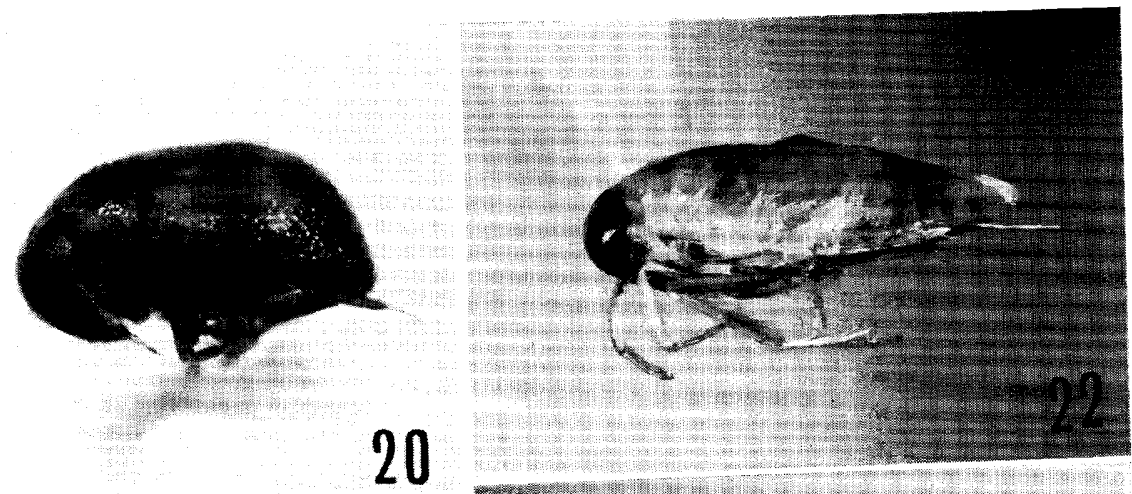

20
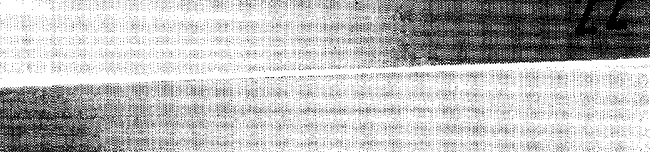

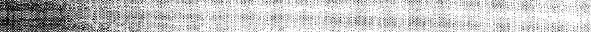

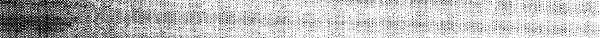

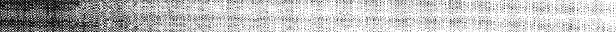

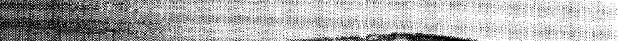

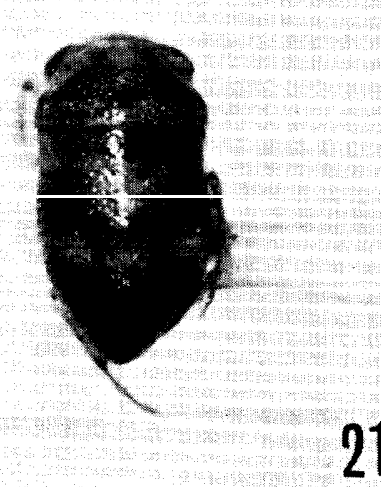

21

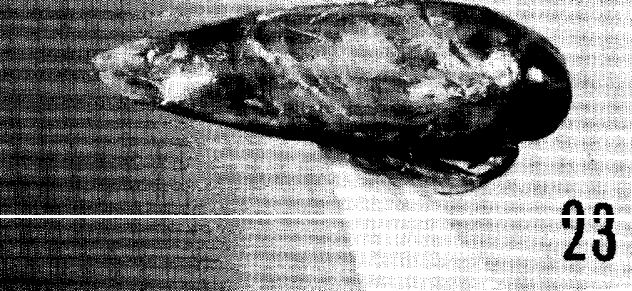

23

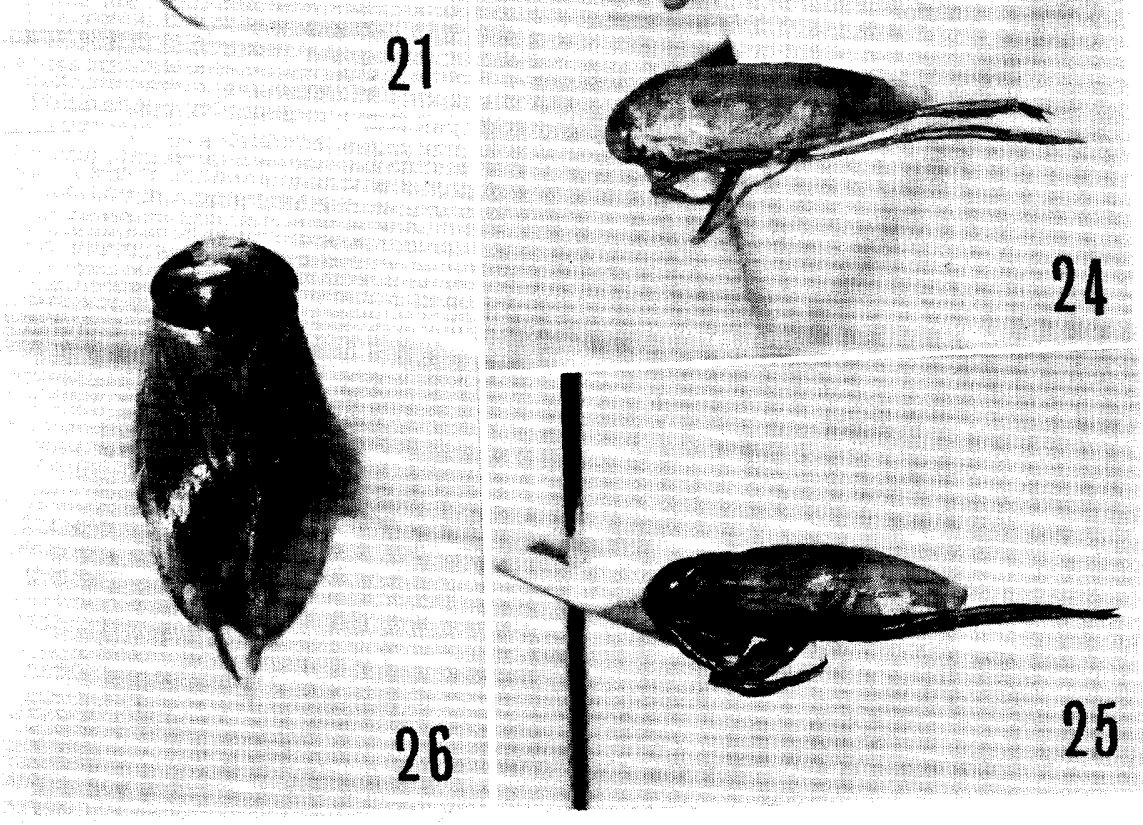


EXPLANATION OF FIGURES

11. Hebrus bergrothi Horváth. Banaue, Ifugao.

12. Mesovelia vittigera Horváth. Tugbok, Davao City.

13. Microvelia douglasi atrolineata Bergroth. Bay, Laguna.

14. Limnogonus fossarum (Fabricius). Banaue, Ifugao.

15. Limnogonus nitidus (Mayr). Tugbok, Davao City.

16. Limnogonus parvulus(Stål), Banaue, Ifugao.

17. Hydrometra Zineata Eschscholtz. Tugbok, Davao City.

18. Hydrometra orientalis Lundblad. Tugbok, Davao City.

19. Ochterus marginatus (Latreille). Pila, Laguna.

20. Paraplea davaoensis Mi ya m o to, sp. nov. Holotype, female. Tugbok, Davao City.

21. Ditto, dorsal view.

22. Anisops kuroiwae Matsumura. Bislig, Surigao del Sur.

23. Anisops nodulata Brooks. Banaue, Ifugao.

24. Anisops yanoi Miyamoto, sp. nov. Paratype, female. Banaue, Ifugao.

25. Enithares martini Kirkaldy. Banaue, Ifugao.

26. Micronecta quadristrigata Breddin. Bislig, Surigao del Sur. 


\section{References}

Brooks, G. T. 1951. A revision of the genus Anisops (Notonectidae, Hemiptera). Univ. Kansas Sci. Bull. 34, pt. 1(1) : 301-519.

Chandra, G. 1978. Natural enemies of rice leafhoppers and planthoppers in the Philippines. Int. Rice Res. Newsletter 3(5): 20-21.

Cheng, L. and C. H. Fernando 1969. A taxonomic study of the Malayan Gerridae (Hemiptera: Heteroptera) with notes on their biology and distribution. Oriental Insects 3: 97160 .

El-Sherif, S. I., A. L. Isa and A. F. Lutfallah 1976. Survey of aquatic insects in rice nurseries and fields. Agr. Res. Rev. 54(1): 93-98.

Esaki, T. 1941. Aquatic and semiaquatic Heteroptera of Manchuria collected by Mr. K. Koba (First report). Trans. Biol.Soc. Manchoukuo 4(2): 117-119. (In Japanese)

Esaki, T. and S. Miyamoto 1955. Veliidae of Japan and its adjacent territory (HemipteraHeteroptera) I. Microvelia Westwood and Pseudovelia Heberlandt of Japan. Sieboldia 1: 169-204.

Fernando, C. H. 1956. The fish fauna of paddy-fields and small irrigation ditches in the western lowlands of Ceylon : and a bibliography of references to fish in paddy fields. Ceylon J. Sci. (C) $7: 225-227$.

Fernando, C. H. 1959. Some observations on aquatic insects found in temporary and artificial habitats in Ceylon. Ceylon J. Sci. (Biol. SC.) 2(1): 1-4.

Fernando, C. H. 1961. Aquatic insects taken at light in Ceylon, with a discussion and bibliography of references to aquatic insects at light. Ceylon J. Sci. (Biol. SC.) 4: 45-54.

Fernando, C. H. 1963. Aquatic Coleoptera and Hemiptera taken at light in some Asian countries with a note on Sphaerodema (Hemiptera-Belostomatidae). Bull. Fish. Res. Stn., Ceylon 16(1): 25-28.

Fernando, C. H. 1965. A preliminary account of the water bugs of the family Corixidae in Ceylon. J. Bombay nat. Hist. Soc.61(3): 603-613.

Fernando, C. H. 1977. Investigations on the aquatic fauna of tropical ricefields with special reference to South East Asia. Geo-Eco-Trap. 3: 169-188.

Fernando, C. H. and L. Cheng 1974. A preliminary study on the fauna and distribution of aquatic Hemiptera in Malaya and Singapore. Federation Mus. Jour. 19: 21-44.

Fernando, C. H., J. I. Furtado and R. P. Lim 1979. The aquatic fauna of the world's ricefields: a general introduction and bibliography of references to the aquatic fauna of ricefields with an introduction to the ecology of the ricefield fauna. Wallaceana Suppl. 2, 105 pp. (Mimeographed)

Fernando, C. H. and C. Y. Leong 1963. Further studies on the water bugs of the genus Anisops (Hemiptera : Notonectidae) in Ceylon. Bull. Fish. Res. Stn.,Ceylon 16(1): 39-48.

Hecktnan, C. W. 1974. The seasonal succession of species in a rice paddy in Vientiane, Laos. Int. Revue ges. Hydrobiol. 59(4) : 489-507.

Heckman, C. W. 1979. Rice field ecology in northeastern Thailand. W. Junk, 228 pp.

Hirashima, Y. 1981. Field studies on the biological control of leafhoppers and planthoppers (Hemiptera: Homoptera) injurious to rice plants in South-East Asia. An account for the year 1979. Esakia (16) : 1-4.

Hiura, I. 1977. Belostomatidae, Nepidae, Gerridae, Hydrometridae, Veliidae, Hebridae, Saldidae, Ochteridae, Notonectidae, Corixidae. pp. 119-129, pls. 31, 33. In: Colouredillustrations of the insects of Japan, II (Ito, S. et al., eds.), Hoikusha Pub. Co. Ltd., Osaka. (In Japanese)

Hutchinson, E. G. 1940. A revision of the Corixidae of India and adjacent regions. Trans. Connecticut Acad.Arts \& Sci. 33: 339-476, 35 pls.

Ito, S. G. 1918. El Arroz. Bol. Min. Agr., Buenos Aires 23(1): 3-123. 
Ito, Y., Ii. Miyahara and K. Sekiguchi 1962. Studies on the predators of the rice crop insect pests, using the insecticidal check method. Jap. J. Ecol. 12: 1-11.

Kenmore, P. E. 1979. Limits of the brown planthopper problem: implications for integrated pest management. IRRI Saturday Seminar, June 30, 1979, pp. 1-33. (Mimeographed)

Kobayashi, T. 1961. The effect of insecticide applications against the rice stem borer on the leafhopper populations. Special research reports on disease and insect forecasting. Tokushima Agr. Exp. Sta. 6: 1-126. (In Japanese with English summary)

Kobayashi, T., Y. Noguchi, T. Hiwada, K. Kanayama and N. Maruoka 1973. Studies on the arthropod associations in paddy fields, with particular reference to insecticidal effect on them. I. General composition of the arthropod fauna in paddy fields revealed by net-sweeping in Tokushima Prefecture. Kontyû41(3): 359-373. (In Japanese with English summary)

Lange, W. H., A. A. Grigarick, C. S. Davis, M. A. Miller, M. D. Miller, R. K. Washino, L. E. Rosenberg, K. L. Rudd and E. W. Jameson 1970. Insect and other animal pests of rice. Circular 555, California Agr. Exp. Sta., Extension Service, 32 pp.

Lansbury, I. 1964. Some observations on the Notonectidae (Hemiptera-Heteroptera) of Viet-Nam and adjacent regions. Ann.Zool.22(10): 203-219.

Lansbury, I. 1967. Aquatic Hemiptera-Heteroptera of the Noona Dan Expedition to the Philippines and Bismarck Islands. Ent. Meddel. 35: 89-98.

Lansbury, I. 1968. The Enithares (Hemiptera-Heteroptera : Notonectidae) of the Oriental Region. Pacific Insects 10(2): 353-442.

Lundblad, 0. 1933. Zur Kenntnis der aquatilen und semiaquatilen Hemipteren von Sumatra, Java und Bali. Arch. Hydrobiol., Suppl. 12. Trop. Binnengew. (4): 1-195, 263-489.

Miura, T. 1969. Studies on the insect association of crop field in San-in District. 5. On the insect association of growing rice plant in protected and lowland rice-nurseries. Bull. Assoc. Plant Prot.Shimane Pref. 3: 1-12. (In Japanese)

Miyamoto, S. 1964a. Veliidae of the Ryukyus (Hemiptera, Heteroptera). Kontyû 32(1): 137150.

Miyamoto, S. 1964b. Semiaquatic Heteroptera of the South-West Islands, lying between Kyushu and Formosa. Sieboldia 3(2): 193-219.

Miyamoto, S. 1965a. Saldidae, Hebridae, Hydrometridae, Veliidae, Gerridae, Belostomatidae, Notonectidae, Corixidae. pp. 101-108, pls. 51-54. In :Iconographia Insectorum Japonicorum Colore naturali edita III (Asahina, S. et al., eds.), Hokuryukan, Tokyo. (In Japanese)

Miyamoto, S. 1965b. [Micronecta from Japan]. Rostria 12: 50-51. (In Japanese)

Moretti, G. P. 1932. Note sulla fauna entomologica delle risaie. Atti Soc. Ital. Sci. Nat. 71 : 61-85.

Nasu, S. 1969. Rice leafhoppers. pp. 493-523. In : The majorinsect pests of the rice plant. Johns Hopkins Press, Baltimore.

Nawa, U. 1924. (Miscellaneous notes on the control of common injurious insects and protection of beneficial insects. 9. Natural enemies of leafhoppers.). Insect World 28: 379-382. (In Japanese)

Oho, N. and M. Fuzii 1956. On the influences of the chemical control to rice stem borer upon the other insects population in rice field in Saga Prefecture. Proc. Assoc. Plant Prot. Kyushu 2: 37-39. (In Japanese)

Oho, N. and K. Miyahara 1957. On Microveliadouglasi Scott as a predator of the rice green leaf-hopper. Proc. Assoc. Plant Pmt. Kyushu 3: 61-62. (In Japanese)

Okada, T. 1900. (Discovery of natural enemies of planthoppers]. Insect World 4: 450-451. (In Japanese)

Pawar, A. D. 197.1. Collection and identification of insect pests of rice. Terminal report. IRRI, 2+67+3 pp. (Mimeographed)

Polhemus, J. T. and W. K. Reisen 1976. Aquatic Hemiptera of the Philippines. Philip. J. 
Biol.5(3) : 259-294.

Riley, C. F. 1922. Food during captivity of the water-striders, Gerris remigis Say and Gerris marginatus Say (Hem.). Ent. News 33 : 86-88.

Sakai, K. 1932. [Microvelia douglasi feeding on leafhoppers]. Kontŷิ 6: 186. (In Japanese)

Sakai, K. 1933. [Seasonal fluctuations of the population of natural enemies of some leaf hoppers in Oita district (2nd report). Additions to the knowledge of natural enemies of some leaf hoppers.). Ôyô-Dôbutsugaku-Zasshi 5: 125-128. (In Japanese)

Sawa, R. 1935. [Soil fauna found in the winter in levee by paddy fields near Mito City). Ôyô-Dôbutsugaku-Zasshi 7(3): 102-104. (In Japanese)

Service, M. W. 1973. Mortalities of the larvae of the Anopheles gambiae Giles complex and detection of predators by the precipitin test. Bull. ent. Res. 62: 359-369.

Service, M. W. 1977. Mortalities of the immature stages of species B of the Anopheles gambiae complex in Kenya: comparison between rice fields and temporary pools, identification of predators, and effects of insecticidal spraying. J. med. Ent.13(4/5): 535-545.

Watanabe, M., Y. Wada, K. Itano and S. Suguri 1968. Studies on predators of larvae of Culex tritaeniorhynchus summorosus Dyar. Jap. J. sanit. Zool. 19(1): 35-38. (In Japanese with English summary)

Weerekoon, A. C. J. and E. L. Samarasinghe 1958. Mesofauna of the soil of a paddy-field in Ceylon. Preliminary survey. Ceylon J. Sci. (Biol. Sci.) l(2) : 155-170.

Yago, M. 1943. [A list of insects injurious to rice, barley and wheat.). Sakumotsu Byogaichu Bojoshiryo (Shizuoka-ken Nokai) 3: 1-52. (In Japanese)

Yano, K. 1978. Faunal and biological studies on the insects of paddy fields in Asia. Part 1. Introduction and Sciomyzidae from Asia (Diptera). Esakia (11) : 1-27.

Yasumatsu, K., Y. Hirashima and K. Yano 1975. Field surveys on the biological control of insect pests and mites in S. E. Asia. General report. Mushi 48(10): 95-123.

Yasumatsu, K., T. Wongsiri, C. Tirawat, N. Wongsiri and A. Lewvanich 1980. Contributions to the development of integrated rice pest control in Thailand. Dept. Agr., Min. Agr. \& Coop., Government of Thailand and Japan Int. Coop. Agency. iv-t163 pp. (Mimeographed)

\section{Addendum}

We overlooked the record of the following subspecies from paddy water.

\section{Gerridae}

Gerris (Aquarius) paludumamamiensis Mi yamot 0

1 우, Ishigaki I., Nansei Is., Japan. (Miyamoto, 1964b) 